\title{
Implementation of Arabic Language and Islamic Values Education (ALIVE) in Marawi City, Philippines: Unveiling the Perceptions of ALIVE Teachers
}

\author{
Saddam Mangondato Solaiman \\ Department of Social Studies, Mindanao State University, Marawi City, Philippines \\ Email address: \\ sadsolai@gmail.com \\ To cite this article: \\ Saddam Mangondato Solaiman. Implementation of Arabic Language and Islamic Values Education (ALIVE) in Marawi City, Philippines: \\ Unveiling the Perceptions of ALIVE Teachers. Education Journal. Vol. 6, No. 1, 2017, pp. 38-46. doi: 10.11648/j.edu.20170601.15
}

Received: October 28, 2016; Accepted: December 24, 2016; Published: February 10, 2017

\begin{abstract}
This study adopts the descriptive research design to gather information about the implementation of Arabic Language and Islamic Values Education (ALIVE) and the prevailing conditions about the teaching of ALIVE in Marawi City, Philippines. A survey was made through questionnaires to assess the implementation of the teaching and the level of effectiveness of the implementation of ALIVE. Findings had shown that there were no sufficient books and learning materials for ALIVE students. Hence, it is also recommended that provision for sufficient updated books and other references for every pupil, making the distribution 1:1ratio be made. Likewise, the data depicted that there is a need to institute reforms on the hiring and in upgrading teacher qualification for them to be truly competent and highly skilled to deliver the goods to intended beneficiaries. Therefore, it is deemed necessary that appointment of qualified and competent ALIVE teachers must be based on merit and fitness. In this vein, there is a need to make the qualifying exam for Arabic language an eligibility to get an employment item. Furthermore, provision of scholarship program for ALIVE teachers should be made available. In the same manner that there is a need for the appointment of competent ALIVE supervisors, consultants or trainers in every district to oversee the program. Lastly as shown from the findings that the ALIVE program was not properly evaluated and monitored. Thus, it is recommended that further study should be conducted to assess the needs of the ALIVE programs and may be an action plan might be proposed to the concerned authority to improve the effective and efficacious implementation of the ALIVE program.
\end{abstract}

Keywords: Arabic Language, Islamic Values, Madrasah Education, Muslim Teachers

\section{Introduction}

The importance of Madrasah education for the Filipino Muslims and the problems of mainstreaming it to the larger national system of education were first noted during the Martial Law years. Perhaps, the Moro rebellion in the early 1970's might have forced the government attention on the importance of Madrasah education.

Many educators in Lanao del Sur and Marawi City that the researcher had a chance to interview observed that during the term of President Marcos, several Letters of Instruction (LOI) were issued mandating integration of Madrasah into Philippine system of education, and authorized the use of Arabic language as a medium of instruction in Arabic subjects among the basic education institutions in the Autonomous Region in
Muslim Mindanao (ARMM). However, as the late Dr. Salipada Tamano has pronounced on many occasions that these efforts to mainstream madrasah education were not extremely successful. Accordingly, during the term of President Gloria Macapagal Arroyo she has made a different approach, a low-key approach by appointing Muslim leaders one after another. To name a few we have Madam Sandra Sema and Atty. Macapanton Abbas Jr., their appointment mandate was to upgrade the quality of Muslim basic education, including the mainstreaming of Madrasah education as a component of the national system of education.

But the actual design and development to mainstreamed madrasah education started only in the early 2002 at the initiative of DepEd-ARMM former Regional Secretary, the late Dr. Mahid M. Mutilan. The effort began with the 
conduct of consultative conference on the design of curriculum for Madrasah Education. Subsequently, Dr. Mutilan issued DepEd ARMM Order No.1, s, 2002, creating the Project of Madrasah Education (PME) with the mandate to design and develop the Madrasah Curriculum.

In August 2004, former DepEd Secretary Edilberto de Jesus authorized the conduct of seminar/workshop on the preparation and unification of Madaris education. The participants were representatives of different organizations that started to work on the design of the curriculum. The final output of the workshop was the basis of DepEd Order No. 51, s 2004, prescribing the standard Curriculum for Madrasah Education in the Philippines. Madrasah Education or ALIVE Program was created to provide Muslim children in the ARMM with quality education that is responsive to their needs to acquire knowledge and skills, with values anchored on the Islamic faith to prepare them for further learning and challenges in society today. (Madrasah Education (2011, March7). SpiritualEducation retrieved from http://www.slideshare.net/gellerico/madrasah-education-

\section{9)}

Moreover, the refined Elementary Madrasah Curriculum, popularly known as ALIVE is the heart of the program.

May Allāh honor him and grant him peace.": sallā llāhu 'alay-hi wa-sallam - S. A. W., SAAW, or SAAS) - this expression follows specifically after uttering the name of Muhammad, although "peace be upon him" may be used instead.

It is a program to guide public elementary schools and private Madaris in the planning, teaching and assessing of Islamic Studies (including Islamic Values Education) and Arabic language within the context of the Philippines education. It provides for an enriched teaching curriculum for public schools as Arabic Language and Islamic Values Education are taught in addition to subjects in the Basic Education Curriculum (BEC) (Refined Elementary Madrasah Curriculum, 2014).

This study is primarily aimed at investigating the level of effectiveness of the implementation of Arabic Language and Islamic Values Education and the problems encountered in teaching ALIVE. The success of this study would help Islamize the learners knowledge that will make them knowledgeable of the Holy Qur'an and the Hadith of the Prophet Muhammad (S. A. W) and hopefully will make the learners emulate the character traits and virtues of Prophet Muhammad (S. A. W) as God-fearing, nationalistic, law abiding, with concern for his fellowmen and the environment, knowledgeable in Arabic, intelligent and industrious and learners that lives up to expectations.

\section{Literature Review}

\subsection{Madrasah Education}

The madrasah or Islamic education in the Philippines is believed to coincide with the growth and coming of Islam, which was brought by Arab missionaries and Malay adventurers who settled in Sulu and western Mindanao. Based on the Sulu Genealogy, in the 13th century, a certain Tuan Mashaika arrived in Sulu and introduced Islam to the inhabitants (Hassoubah, 1983).

A later missionary by the name of Karim-ul-Makhdum arrived during the second half of the 14th century, and his religious activities reinforced the growing Islamic community in Sulu (Abubakar). Makhdum was followed by a decade or so, later by a Sumatran Muslim nobleman, Rajah Baguinda, who instituted himself into the local Sulu leadership and furthered the spread of the teachings of Islam (Hassoubah, cited in Alonto, 1986).

In the beginning of 15 th century, another Arab missionary, Sayyid AbūBakr also known as Sharif-ulHashim, landed in Jolo Island. Abu Bakr consolidated political power by introducing the sultanate as a political system with himself becoming the first sultan. His 30-year reign saw the construction of mosques and the establishment of madaris (Abubakar).

Madrasah education was mostly done in the house of the pandita or guro, a Sanskrit word for "teacher." Sometimes classes were also done in the masjid or mosque. Lessons were confined to the reading and writing of the Arabic language as the means of reading the Qur'an (Hasoubah, 1983).

During the period of Moro resistance against the colonizers Madrasah Education was the single institution that made the survival of Islam possible in the Philippine. During the Spanish period, Madrasah was the only form of education available. During the American period, the western system of secular education was introduced in Mindanao, Sulu and Palawan. However the Moro Muslims rejected the western concept of education, thinking that it would Christianize their children. The acceptance by Moro Muslims of secular system of education in the public (government) schools was slow and gradual.

After the declaration of independence and amidst the massive migration of Christian settlers in Mindanao, the participation rate of Moro Muslims in the public schools increased rapidly. The current rate is above $90 \%$. The evolution in Madrasah education began in the 1950's, when the Moro were sent to study to the Muslim countries. When these scholars returned to the Philippines, they established formal madrasah institutions offering the same Islamic sectarian curriculum that they learned from Universities abroad.

There are laws signed and issued by former President Ferdinand E. Marcos pertaining to the recognition of Islamic heritage as part of the Filipino culture. One of these laws was a Letter of Instruction (LOI) 71-A which was signed into law by former President Ferdinand E. Marcos on April 28, 1973. This law allows the use of Arabic as a medium of instruction in areas where Muslims are dominant, which was enforced in the early 1970's. Another law was Letter of Instruction (LOI) 1221 and signed into law on March 31, 1982. The said law served as basis for gradual integration of the madrasah into Philippines educational system. 
Another law that was recently issued by the Department of Education (DepEd) was DepEd Order No.51, s. 2004, which was developed in 2004 which is the Madrasah Education Program for Filipino Muslim learners. The said law prescribed the adoption of the standard Madrasah Curriculum Framework in the public elementary schools and private Madaris.

For the past five years, the number of implementing schools has grown as DepEd continues to provide resources in terms of materials and capacity building programs for teachers, as well as assists the private Madaris during transition and advocates the program in all regions.

The Madrasah Education Program was created to provide Muslim children with quality education that is responsive to their needs, a good foundation for their knowledge and skills, with values anchored on the Islamic faith to prepare them for further learning and challenges in society today (Maruhom, 2012).

Aside from DepEd Order No. 51, series of 2004, there are other laws that supplement and reinforce the said law. These are:

a DepEd Order No. 46 s. 2005 that explained the operational guidelines for the implementation of DepEd Order No. 51 s. 2004;

b DepEd Memorandum No. 56 s. 2006, the guidelines of the intensified training of Muslim teachers in Arabic language and Islamic Values in public schools and guidelines in the selection and hiring of Asatidz or Muslim teachers for school year 2006-2007;

c DepEd Order No. s. 2007, which is for the allocation of new teacher items for school year 2007-2008;

d DepEd Memorandum No. 250 s. 200 enumerates the guidelines in the payment of allowances of Muslim teachers (Asatidz) of the Arabic Language and Islamic Values Education (ALIVE) in the public elementary schools;

e DepEd Order No. 81 s. 2007further elaborates assistance to private madrasah and the incentive to adopt the standard curriculum as authorized under DepEd Order No. 51 s. 2004 and the total mainstreaming of madrasah education as a component of the national system of Basic Education; and

f DepEd Order No. 18 s. 2008, the implementing guidelines for DepEd Order No. 81 s. 2007 for financial assistance to private madrasah.

\subsection{Arabic Language}

The Arabic language is the language of our enduring religion, which is Islam. The Qur'ân was revealed in Arabic. Allah (S. W. T) says: "Indeed We have made it an Arabic Qur'ân that perchance you will comprehend." [Al-Qur'an 43:37 The above quoted verse in the Holy Qur'an shows that the Arabic language is not merely a language of the Arabs but a language of all Muslim that must be learnt in order to understand Islam that is why the Arabic Language and Islamic Values Education (ALIVE) program has been implemented in the ARMM. The program has been introduced in the curriculum of every school that had a significant number of Muslim enrolees in order to educate the Muslim children because it is obligatory as what Allah (swt) said in His holy Book, the Holy Qur'an.

There was a hadith narrated by 'Umar (may Allah be pleased with him), he said: 'Learn Arabic for it is part of your religion, and learn how the estate of the deceased should be divided (fara'id) for these are part of your religion.'

The hadith stated above shows how important Arabic language is for Islam wherein it is obligatory to every Muslim who embrace Islam as his/her religion same with learning the Sharia law. According to 'Umar, to learn Arabic and Shari'ah should be combined, for religion involves understanding words and actions. Understanding Arabic is the way to understand the words of Islam. Understanding the Sunnah is the way to understand the actions of Islam (Islamic Treasure Website, 2015).

\subsection{Related Studies}

"According to Maruhom (10)" in her study "The Readiness and Competencies of Arabic Language and Islamic Values Education Teachers in the Non-Muslim and Muslim Regions in Mindanao", the top five problems perceived by the respondents in teaching Arabic Language and Islamic Values Education subjects were: (i) lack of items for qualified ALIVE teachers; (ii) no materials available for visual aids; (iii) scarce and limited books for Arabic language and Islamic Values Education; (iv) problems in the recruitment of qualified ALIVE teachers who have appropriate degree; and (v) lack of training and orientation, and seminar of ALIVE teachers in Arabic Language and Islamic values innon-Muslim areas.

The top five suggestions of ALIVE teachers in Muslim areas were: (i)there must be qualified ALIVE consultants and trainers in every division or district; (ii) standardization and augmentation of learning materials for the subjects especially by having textbooks for the Islamic and Arabic curriculum; (iii) textbooks for students must be reproduced to implement one student-one book policy; (iv) provide scholarship grants to ALIVE teachers through short or long range plan; and (v) increase the salary of ALIVE teachers to become at least equal to the salary of Teacher 1 . In non Muslim areas, the top five suggestions in improving program were: (i) to make classroom facilities and equipment provided appropriately;

Umar full name was Umar Ibn Al-Khattab ibn Nufayl ibn Abdul Uzza, he was succeeded Abu Bakr as a second caliph on August 23,634, he was an expert jurist and best known for his justice, in the same way for Muslims and non-Muslims and who presided over the Muslim state after the Prophet (S. A. W) death.

(ii) accelerate teacher training program for both public and accredited private schools; (iii) increase the salary of ALIVE teachers to be at least equal to Teacher 1; (iv) standardization and augmentation of learning materials especially textbook for the Islamic Arabic curriculum; and (v) an ALIVE Institute must be established to cater the needs of teachers 
particularly in holding trainings and seminars in implanting the program.

The appointment of qualified ALIVE consultants and trainers in every district or division is also recommended in the study as well as the formation of an Islamic and Arabic textbook writing committee in ARMM who will publish and distribute references for ALIVE. Regarding the employment of ALIVE teachers, it is further recommended that ALIVE teacher training programs and seminars be credited in lien of bachelor's degree to take the civil service examination. As civil service eligibility for appointment in DepEd schools, the paper further recommended that longevity or five years of efficient service as ALIVE teacher and the Arabic Qualifying Examination (AQE) should be used. Lastly, study now pay later grants should be made available for ALIVE teachers to pursue post graduate studies.

Hassoubah (1983) showed that the Madrasah should remain as an Islamic institution transmitting to generations of students knowledge in Islamic and Arabic studies. Among the measures that would guarantee its existence and increase its relevance include the following:

a Revision of the curriculum. Courses such as English, vocational education, Philippine history, home economics and Philippine Citizenship should be incorporated in the curriculum to give it more social and economic relevance in the Philippine context. Public school teachers might well be detailed by the education authorities to teach such courses in the madrasah.

b Accreditation and recognition of the madrasah. The Ministry of Education and Culture should oversee operations of the madrasah in consonance with some universal standards so as to ensure uniformity of instruction and quality education.

c All-out training and upgrading of the skills of Arabic teachers in the madrasah. With the help of Ministry of Education and Culture, Mindanao State University, through the King Faisal Center for Islamic and Arabic Studies, and foreign agencies such as the world Federation of Islamic International Schools, every effort to improve the quality of Arabic teaching should be made. This requires allocating funds purposely for the training of Arabic teachers;

d An all-out production of instructional materials in Arabic and Islamic courses with the help of government as well as outside agencies;

e Admission of graduates of recognized or accredited madaris to Philippine universities. Madrasah graduates ought to be allowed to further their education especially in institutions with Islamic and Arabic programs such as Mindanao State University and the University of the Philippines. Scholarship grants should be awarded to deserving madrasah graduates who wishes to pursue programs in teaching Arabic as a second language (offered by King Faisal Center for Islamic, Arabic and Asian Studies) and related courses; and

f Setting up professional standards for Arabic teachers.

\section{Methodology}

This study adopts the descriptive survey research design. This was used to describe the profile of the respondents and to gather information about their perception in teaching Arabic Language and Islamic Values Education. A survey was made through administering questionnaires to the respondents for the necessary data needed in the study.

This study was conducted in public elementary schools in Marawi City Division. Marawi City, a component city in the province of Lanao del Surin the Autonomous Region in Muslim Mindanao belongs to the Mindanao group of islands. This component city is seated about $816 \mathrm{~km}$ south-southeast of the Philippine's main capital Manila.

The Autonomous Region of Muslim Mindanao (ARMM) was created in August 1, 1989 by virtue of Republic Act No. 6734 (Organic Law) as contained in the 1987 Constitution. The ARMM included the four (4) provinces of Lanao del Sur, Maguindanao, Sulu, and Tawi-Tawi. However, it was actually implemented and inaugurated on November 6, 1990 under the presidency of Corazon Aquino in Cotabato City, the seat of the Regional Government. A plebiscite on the Expanded ARMM Law in 14 provinces and cities of Mindanao and Palawan was conducted on August 14, 2001 to ask the constituents whether they wanted to be included in the ARMM. The results showed that only Basilan province (excluding Isabela City) and Marawi City voted YES to join the ARMM. Marawi City, formerly Dansalan City, is the capital city of Lanao del Sur. There are five (5) division offices of the Department of Education in this province and in Marawi city. It has more than twenty (20) tertiary schools including the Mindanao State University. Marawi City is a separate division with seven (7) public high schools and a total of five thousand and four hundred ninety-six high school students $(5,496)$.

There are fifty-four (54) public elementary schools in Marawi City that implement the provisions of the different DepEd orders pertaining to the inclusion of ALIVE in their curriculum. The respondents of the study were one hundred (100) ALIVE teachers in Marawi City Division. They were selected using purposive and simple random sampling by using raffles by putting all names of ALIVE teachers in Lanao del Sur and Marawi City in a box and the researchers requested a friend to pick up samples of one hundred names.

A survey questionnaire was utilized to gather the necessary data. It has three parts. The first part deals with the profile of the respondents where they check the appropriate choice that reflects their profile. The second part intended to gather data on the level of effectiveness of the implementation of ALIVE in various aspects, namely, teacher competency, school facilities, instructional materials, DepEd support and LGU support. In this part, the respondents decide whether the said aspects are implemented with the following qualities: very poor, poor, good, and very good. The third part of the questionnaire was concerned with the problems encountered by the respondents in teaching ALIVE where they identify through a checklist the problems they encountered among the 
enumerated choices.

To gather the primary data needed for the study, the researcher used a structured questionnaire that was presented to the committee for their approval. Letters were prepared addressed to the Division ALIVE Coordinator of the Marawi City Division to allow the researcher to distribute the questionnaires. When the request was granted, the researcher personally administered the questionnaire to the teacher respondents.

The data gathered were treated using the statistical tools, which were deemed most appropriate for the study, and approved by the committee when it was presented. Finally, the questionnaires were retrieved and the data were then gathered and analyzed.

\section{Results and Discussion}

\subsection{Profile of ALIVE Teachers}

Many of the respondents were in the 26-30 years old range composed by 37 or $37.0 \%$ of the respondents followed by $36-$ 40 years old with comprises 27 or $27.0 \%$ of the respondents. Majority $63.0 \%$ of the respondents were females while $37.0 \%$ of the respondents were males, majority of $59.0 \%$ of the ALIVE teachers were married and only $38.0 \%$ of the respondents were single. Majority of the respondents in Marawi City were Meranaw comprising 96\% of the respondents followed by a population of $1 \%$ comprised of Maguindanaons while the rest of the respondents did not state their ethnicity, many or fifty $(50.0 \%)$ of the respondent were high school graduates while $35.0 \%$ were college graduates and other $26.0 \%$ were master degree holders in secular education, forty eight percent $48.0 \%$ were master's degree holders in madrasah education while $35.0 \%$ were college graduates in madrasah and only $17.0 \%$ were high school graduates in madrasah education.

Majority or $82.0 \%$ of the respondents were passers of the Qualifying Examination for Arabic Language and Islamic Studies and $14.0 \%$ are passers of the Licensure Examination for Teachers (LET) while $4.0 \%$ of the population are passers of the Philippine Board Examination for Teachers (PBET). The employment status of $100.0 \%$ of the respondents were contractual and seventy seven percent $77.0 \%$ of the population had one to three years of teaching experience in secular education while $11.0 \%$ had four to six years of experience. About $5.0 \%$ had ten to fifteen years of experience in secular education. Only $1.0 \%$ of the respondents had more than 25 years of teaching experience in secular education. As to their work experience in the madrasah, about $20.0 \%$ of the respondents had four to six years of teaching experience while there were $19.0 \%$ of the respondents who had one to three years of experience and others, $18.0 \%$ of the respondents had ten to fifteen years of teaching experience. The other $15.0 \%$ of the respondents had seven to nine years of teaching experience in madrasah education. Forty six percent $46.0 \%$ of the respondents have attended three to four seminars or trainings relating to the
ALIVE program while $41.0 \%$ of the respondents attended four or more seminars or trainings However, only $13.0 \%$ of the respondents have attended one to two seminars or trainings. One hundred percent $100.0 \%$ of the population receives a Php 6,000 monthly salary/honorarium from the Department Education for involving in the ALIVE program. Ninety percent $90.0 \%$ of the respondents receive no allowance or honorarium from their local government unit and while two percent $2.0 \%$ receives an allowance ofPhp1,000 from their local government unit. Another one percent $1.0 \%$ received an allowance, of $\mathrm{Php} 3,000$ to Php6,000 every month. While five percent $5.0 \%$ of the respondents receives a monthly allowance of Php6,000 above.

Table 1. Frequency and Percentage Distribution of Respondents According to Age.

\begin{tabular}{lll}
\hline Age & Frequency & Percentage \\
\hline $18-25$ & 16 & 16.0 \\
$26-30$ & 37 & 37 \\
$36-40$ & 27 & 27 \\
Above 40 years old & 20 & 20 \\
Total & 100 & 100 \\
\hline
\end{tabular}

Table 2. Frequency and Percentage Distribution of Respondents According to Sex.

\begin{tabular}{lll}
\hline Sex & Frequency & Percentage \\
\hline Male & 37 & 37.0 \\
Female & 63 & 63.0 \\
Total & 100 & 100.0 \\
\hline
\end{tabular}

Table 3. Frequency and Percentage Distribution of Respondents According to Civil Status.

\begin{tabular}{lll}
\hline Civil Status & Frequency & Percentage \\
\hline Single & 38 & 38.0 \\
Married & 59 & 59.0 \\
Widow/Widower & 3 & 3.0 \\
Total & 100 & 100.0 \\
\hline
\end{tabular}

Table 4. Frequency Distribution of Respondents According to Ethnic Affiliation.

\begin{tabular}{lll}
\hline Ethnicity & Frequency & Percentage \\
\hline Maguindanaon & 1 & 1.0 \\
Meranao & 96 & 96.0 \\
others not mentioned & 3 & 3.0 \\
Total & 100 & 100.0 \\
\hline
\end{tabular}

Table 5. Frequency and Distribution of Respondents According to Highest Educational Attainment in Secular Education.

\begin{tabular}{lll}
\hline Educational Attainment & Frequency & Percentage \\
\hline High school Graduate & 50 & 50.0 \\
Undergraduate Degree & 24 & 24.0 \\
Graduate Degree & 26 & 26.0 \\
Total & 100 & 100.0 \\
\hline
\end{tabular}


Table 6. Frequency and Percentage Distribution of Respondents According to Highest Educational Attainment in Madrasah Education.

\begin{tabular}{lll}
\hline Educational Attainment & Frequency & Percentage \\
\hline High school Graduate & 17 & 17.0 \\
Undergraduate Degree & 35 & 35.0 \\
Graduate degree & 48 & 48.0 \\
Total & 100 & 100.0 \\
\hline
\end{tabular}

Table 7. Frequency and Percentage Distribution of Respondents According to Eligibility.

\begin{tabular}{lll}
\hline Eligibility & Frequency & Percentage \\
\hline LET Passers & 14 & 14.0 \\
PBET Passers & 4 & 4.0 \\
QEALIS & 82 & 82.0 \\
Total & 100 & 100.0 \\
\hline
\end{tabular}

Table 8. Frequency and Percentage Distribution of Respondents According to Appointment Status.

\begin{tabular}{lll}
\hline Appointment & Frequency & Percentage \\
\hline Contractual & 100 & 100.0 \\
Permanent & 0 & 0 \\
\hline
\end{tabular}

Table 9. Frequency and Percentage Distribution of Respondents according to Number of Years of Teaching in Secular Education.

\begin{tabular}{lll}
\hline Years & Frequency & Percentage \\
\hline 1 to 3 & 77 & 77.0 \\
4 to 6 & 11 & 11.0 \\
7 to 9 & 2 & 2.0 \\
10 to 15 & 5 & 5.0 \\
16 to 20 & 4 & 4.0 \\
Above 25 years & 1 & 1.0 \\
Total & 100 & 100.0 \\
\hline
\end{tabular}

Table 10. Frequency and Percentage Distribution of Respondents According to Number of Years of Teaching in Madrasah Education.

\begin{tabular}{lll}
\hline Years & Frequency & Percentage \\
\hline No answer & 13 & 13.0 \\
1 to 3 & 19 & 19.0 \\
4 to 6 & 20 & 20.0 \\
7 to 9 & 15 & 15.0 \\
10 to 15 & 18 & 18.0 \\
16 to 20 & 8 & 8.0 \\
21 to 25 & 5 & 5.0 \\
Above 25 years & 2 & 2.0 \\
Total & 100 & 100.0 \\
\hline
\end{tabular}

Table 11. Frequency and Percentage Distribution of Respondents According to The Number of Seminars /Trainings Attended.

\begin{tabular}{lll}
\hline Numbers Seminars/Training & Frequency & Percentage \\
\hline 1 to 2 & 13 & 13.0 \\
3 to 4 & 46 & 46.0 \\
Above 4 & 41 & 41.0 \\
Total & 100 & 100.0 \\
\hline
\end{tabular}

Table 12. Frequency and Percentage Distribution of Respondents According Monthly Salary/Honorarium.

\begin{tabular}{lll}
\hline Salary & Frequency & Percentage \\
\hline Php6,000-10,000 & 100 & 100.0 \\
Other Compensation & None & 0 \\
\hline
\end{tabular}

Table 13. Frequency and Percentage Distribution of the Respondents According to Monthly Allowance from Local Government Unit (LGUs).

\begin{tabular}{lll}
\hline Allowance LGU & Frequency & Percentage \\
\hline None & 90 & 90.0 \\
Below 1,000 & 2 & 2.0 \\
$1,000-3,000$ & 2 & 2.0 \\
$3,000-6,000$ & 1 & 1.0 \\
Above 6,000 & 5 & 5.0 \\
Total & 100 & 100.0 \\
\hline
\end{tabular}

\subsection{Effectiveness of ALIVE Implementation}

Table 14 presents the weighted mean (WM) ratings of the statements on level of effectiveness of implementing of ALIVE in Marawi City. As indicated in the table, the over-all weighted mean is 2.23 described as "Undecided". The top 5 statements on level of effectiveness among the respondents are as follows: There is no strict supervision to ALIVE teaching (WM=2.94, agree); No regular upgrading of ALIVE materials e.g textbooks and other references $(\mathrm{WM}=2.92)$; The ALIVE teachers use traditional methods of teaching, e.g chalk and blackboard (WM=2.85); An ALIVE teacher must have skill in guidance and counselling (WM=2.75); An ALIVE teacher must possess an ability to listen to students needs $(\mathrm{WM}=2.70)$.

On the other hand, there were effectiveness statements that the respondents in Marawi City"disagree". These are as follows: The ALIVE teachers update their instructional materials ( $\mathrm{WM}=1.35$, disagree); Willingness to give services despite bad weather and in not good working condition (WM=1.45, disagree); An ALIVE teacher should be updated on concepts and ideas he/she is discussing (WM=1.54, disagree); There is enough support from DepEd on ALIVE program (WM=1.54, disagree). 
Table 14. Level of Effectiveness of ALIVE in terms of Various Indicators.

\begin{tabular}{|c|c|c|}
\hline Indicators & \multirow{2}{*}{ WM } & \multirow{2}{*}{ Description } \\
\hline A. Teacher Competency & & \\
\hline \multicolumn{3}{|l|}{ 1. Knowledge } \\
\hline - An ALIVE teacher should have sufficient knowledge on the topic he/she is discussing. & 2.50 & Agree \\
\hline - An ALIVE teacher must have adequate training on his/her field of discipline. & 2.43 & Agree \\
\hline - An ALIVE teacher should be updated on concepts and ideas he/ she is discussing. & 1.54 & Disagree \\
\hline - An ALIVE teacher must be well prepared on his/her lesson. & 2.58 & Agree \\
\hline - An ALIVE teacher should have a good background on the subject matter he/she is handling. & 2.35 & Undecided \\
\hline \multicolumn{3}{|l|}{ 2. Attitude } \\
\hline - An ALIVE teacher has commitment and dedication on his/her assigned task. & 2.28 & Undecided \\
\hline - An ALIVE teacher must have loyalty to her/his institution. & 2.10 & Undecided \\
\hline - Willingness to serve even with less remuneration and an epitome of compassion. & 2.34 & Undecided \\
\hline - Willingness to give services despite bad weather and in not good working condition. & 1.45 & Disagree \\
\hline - Willingness to extend extra effort to provide good services to pupil that needed special attention. & 1.70 & Undecided \\
\hline \multicolumn{3}{|l|}{ 3. Skills } \\
\hline - An ALIVE teacher is a good facilitator of learning. & 2.55 & Agree \\
\hline - An ALIVE teacher is a good repository of materials for learning or a librarian. & 2.57 & Agree \\
\hline - An ALIVE teacher must have skill in guidance and counselling. & 2.75 & Agree \\
\hline - An ALIVE teacher must be good communicator of ideas. & 2.53 & Agree \\
\hline - An ALIVE teacher must possess an ability to listen to students' needs. & 2.70 & Agree \\
\hline \multicolumn{3}{|l|}{ B. School Facilities } \\
\hline - The ALIVE rooms are conducive to learning. & 2.04 & Undecided \\
\hline - The ALIVE rooms are not conducive to learning. & 2.23 & Undecided \\
\hline - The ALIVE rooms are well equipped with devices, reading materials and etc. & 2.13 & Undecided \\
\hline - The ALIVE rooms have good ambiance to learning. & 2.28 & Undecided \\
\hline - The ALIVE rooms do not have good ambiance. & 1.65 & Undecided \\
\hline \multicolumn{3}{|l|}{ C. Instructional Materials } \\
\hline - There are enough textbooks available on school related activities. & 1.65 & Undecided \\
\hline - There are no enough text books available in school in ALIVE. & 2.42 & Agree \\
\hline - The ALIVE teachers are using traditional method of teaching e.g. chalk and blackboard. & 2.85 & Agree \\
\hline - The ALIVE teachers update their instructional materials. & 1.35 & Disagree \\
\hline - The ALIVE teachers use obsolete instructional materials. & 2.69 & Agree \\
\hline \multicolumn{3}{|l|}{ D. Local Government Units Support } \\
\hline - There is enough support from LGU that is provided to ALIVE program. & 2.08 & Undecided \\
\hline - There is no enough support from LGU that is given to ALIVE program. & 1.95 & Undecided \\
\hline - The support of LGU to ALIVE is inadequate. & 1.96 & Undecided \\
\hline - The support of LGU to ALIVE is meagre. & 1.96 & Undecided \\
\hline - The support of LGU to ALIVE is consistent. & 2.02 & Undecided \\
\hline \multicolumn{3}{|l|}{ E. Department of Education Support } \\
\hline - No regular upgrading of ALIVE materials e.g textbooks and other references. & 2.92 & Agree \\
\hline - There is no strict supervision to ALIVE teaching & 2.94 & Agree \\
\hline - There is enough support from DepEd on ALIVE program. & 1.54 & Disagree \\
\hline - There is no enough support from DepEd on ALIVE program. & 2.52 & Agree \\
\hline - The support of DepEd is inadequate on ALIVE program. & 2.51 & Agree \\
\hline
\end{tabular}

\subsection{Problems Encountered in Teaching ALIVE}

In Table 15, problems encountered by the respondents in relation to the teaching of ALIVE and the implementation of the program are tabulated. It can be gleaned that the top problem identified by the respondents is the delay of salary and honorarium. This is perhaps the reason why the respondents perceived the DepEd's and LGU's support as poor.

The second problem is the lack of support from Local Government Units, which is apparent in the previous data where respondents perceived LGU's support as very poor. Another problem encountered by the respondents is the scarcity and limited supply of books. Although the respondents perceived instructional materials as good, it does not mean that there is enough supply of them. The quality of such materials might be good but their availability and accessibility are not particularly ensured. Thus, the fourth problem that is the lack of classroom supplies and instructional materials in teaching ALIVE is apparently an existing phenomenon.

Not only the salary and allowance are delayed, they are also insufficient, considering the needs and other expenses of ALIVE teachers. To reiterate the previous data on the respondents' salary and allowance, the majority of the respondents receive only $6,001-10,000$ pesos monthly salary 
while in allowance, the majority do not receive anything at allowance clearly could not suffice for their needs.

all. Thus, this indicates that the provision of salary and

Table 15. Problems Encountered by Teachers in Teaching ALIVE.

\begin{tabular}{|c|c|c|c|}
\hline Indicators & Mean & Std. Deviation & Rank \\
\hline Delayed Salary/honorarium & 0.970 & 0.171 & 1 \\
\hline Lack of Support from Local Government Units & 0.810 & 0.394 & 2 \\
\hline Scarce and Limited books & 0.780 & 0.416 & 3 \\
\hline Lack of classroom supplies and instructional materials in teaching of ALIVE & 0.770 & 0.423 & 4 \\
\hline Insufficient salaries/allowances provided by the Government & 0.750 & 0.435 & 5 \\
\hline Lack of Trainings/Seminars in teaching of ALIVE & 0.280 & 0.451 & 6 \\
\hline Lack of Supervision from the DepEd & 0.120 & 0.327 & 8 \\
\hline
\end{tabular}

\section{Conclusion and Recommendations}

Based on the findings of the study, it is concluded that the typical ALIVE teacher is a young high school graduate in secular education, female, a Meranaw, no teaching license but is a passer of the Qualifying Examination for Arabic Language and Islamic Studies before being appointed as ALIVE teacher. They have an employment contractual status, with three years or less teaching experience in a secular school and more than ten years in madrasah education. They have participated in three or more seminars or training, receiving a monthly salary from the Department of Education (DepEd) are few receiving a small amount of allowance from Local Government Units (LGUs).

ALIVE teachers in Marawi City have average school facilities and sufficient instructional materials as well as insufficient salaries received from DepEd and lack of support from local government units. ALIVE teachers however, are competent to teach the ALIVE subjects. The major problems in teaching of ALIVE were delayed salaries from DepEd, lack of support from local government units, scarce and limited books, and insufficient classroom supplies provided by DepEd.

Based on the findings, the following implications are hereby advanced. It can be implied that although the ALIVE program is a mandate of the government, however its implementation is not properly evaluated and monitored as gleaned from the less support and attention given to it by concerned proper authority like the DepEd and LGU's. Moreover, it could be clearly deduced that the success of the ALIVE program is dependent from the support of the National Government for proper allocation funding and itemized position. Furthermore, it is also indicated in the data that ALIVE teachers are qualified and is committed in their work but they can only do so much in accordance with the limited resources provided to them.

Based on the findings and Implications of the study, the following are recommended. As gleaned from the data gathered that ALIVE teachers' salary was not based on the Salary Standardization Law, as it seems that it is only in the forms of an allowance, which was not released on monthly bases but most of the time, delayed. Thus, it is highly recommended that provision for sufficient salary or honorarium for the ALIVE teachers should be given and should be given on time. Moreover, LGUs financial assistance to ALIVE teachers must be uniform. Findings also had shown that there were no sufficient books and learning materials for ALIVE students given. Hence, it is also recommended that provision for sufficient updated books and other references for every pupil, making the distribution $1: 1$ ratio be made.

Likewise, the data depicted that there is a need to institute reforms on the hiring and in upgrading teacher qualification for them to be truly competent and highly skilled to deliver the goods to intended beneficiaries. Therefore, it is deemed necessary that appointment of qualified and competent ALIVE teachers must be based on merit and fitness. In this vein, there is a need to make the qualifying exam for Arabic language an eligibility to get an employment item. Furthermore, provision of scholarship program for ALIVE teachers should be made available. In the same manner that there is a need for the appointment of competent ALIVE supervisors, consultants or trainers in every district to oversee the program.

Lastly, as shown in the findings, the ALIVE program was not properly evaluated and monitored. Thus, it is recommended that further study should be conducted to assess the needs of the ALIVE programs and may be an action plan might be proposed to the concerned authority to improve the effective and efficacious implementation of the ALIVE program.

\section{References}

[1] Abdulrahman, J. A. (2012) Questions and Answer: Islamic Law (Shariah) and Jurisprudence (Fiqh). Iligan City, Philippines: Ivory Printing and Publishing House.

[2] Al-Hilali, M. M (2006). Translation of the Meaning of the Noble Qur'an in the English language King Fahd Complex for the printing of holy Qur'an madinah, KSA.

[3] Aquino, G. V. (2003). Effective Teaching. Mandaluyong City, Philippines: National Bookstore.

[4] Department of Education. (2014). Refined Elementary Madrasah Curriculum. Department of Education, Office of Madrasah Education. Sampaloc, Manila: MGO Enterprises. 
[5] Dimacaling, M. D. (1994). The Arabic Language Teaching at the King Faisal Center for Islamic. Arabic and Asian Studies: Status, Problems and Prospects. Unpublished Master Thesis, Mindanao State University, Marawi City.

[6] Enterino, O. N. (2004). Approaches in Teaching Arabic Language at the King Faisal Center for Islamic, Arabic and Asian Studies of the Mindanao State University, Marawi City. Unpublished Master Thesis, Mindanao State University, Marawi City.

[7] Hassoubah, A. M. (1983). Teaching Arabic as a Second Language in the Southern Philippines. MSU, Marawi City: University Research Center.

[8] Imam Hafiz, A. I. (2007). English Translation of Jami' AtThirmidhi, Maktaba Dar-us-Salam, King Fahd National Library Catalogue in Publication Data.

[9] Maruhom, M. M. (2012). Readiness and Competencies of Arabic language and Islamic Values Education (ALIVE) Teachers in the Non-Muslim and Muslim Regions in Mindanao: Basis for Policy Making. Published Dissertation, Mindanao State University, Marawi City.

[10] Maruhom, M. M. (2006). The Value of Teaching Arabic in the Accredited Madaris Offering Shariah in Marawi City as a Basis for Training Model. Unpublished Master Thesis, Mindanao State University, Marawi City.

[11] MSU, G. F (2013). Graduate Forum Volume 10. Nos. 1, 2, \& 3 January-December 2013 Graduate School Center, Mindanao State University, Marawi City.
[12] Philips, A. B. (2007). The Evolution of Fiqh. Malaysia: A. S. Noordeen.

[13] Rodriguez, L. D. (1996). A Madrasah General Education program for Muslim Mindanao. Iligan City: Ivory Printing and Publishing House.

[14] Sarip, A. D. (2003). The Implementation of Arabic Language Teaching Training Model. Unpublished Dissertation, Ateneo de Zamboanga University, Zamboanga City, Philippines.

[15] Tejero-galero, E. (2011). A Simplified Approach to Thesis and Dissertation Writing. Mandaluyong City: National Bookstore.

\section{Biography}

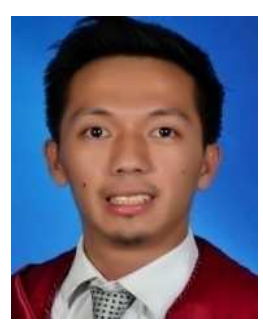

Saddam Mangondato Solaiman is a 25 years old faculty member of Siawadato Community High School- Mindanao State University main campus, Marawi City, Philippines. He earned the degree of Bachelor of Science in International Relations and Master of Arts in Islamic studies and currently taking up Doctor of Philosophy in Philippines Studies in MSU- Marawi City. He is a licensed Social Studies teacher and licensed Islamic Studies and Arabic Language teacher. His research interests include Islamic Education, Arabic language and Arab culture. 